\title{
Ecological parameters of the endohelminths in relation to size and sex of Prochilodus argenteus (Actinopterygii: Prochilodontidae) from the Upper São Francisco River, Minas Gerais, Brazil
}

\author{
Cassandra M. Monteiro ${ }^{1}$; Michelle D. Santos ${ }^{1}$; Nágila A. Zuchi ${ }^{1}$ \& Marilia C. Brasil-Sato ${ }^{1,2}$ \\ ${ }^{1}$ Departamento de Biologia Animal, Universidade Federal Rural do Rio de Janeiro. Rodovia BR 465, km 7, Caixa Postal \\ 74539, 23851-970 Seropédica, Rio de Janeiro, Brasil. \\ 2 Corresponding author. E-mail: mcbsato@ufrri.br
}

\begin{abstract}
This research aimed to investigate the ecological indexes of the helminths of the digestive system and coelom of Prochilodus argenteus Spix \& Agassiz, 1829. A total of 150 specimens (53 males and 97 females) taken from the upper reaches of the São Francisco River in the municipality of Três Marias (18 $\left.12^{\prime} 32^{\prime \prime} S, 45^{\circ} 15^{\prime} 41^{\prime \prime} \mathrm{W}\right)$, State of Minas Gerais, Brazil, were examined. The specimens were collected in July, 2003 and January, 2004. Ninety-eight fish (65.3\%) were infected by at least one species of helminth. Five helminth species were found: one digenean, Saccocoelioides nanii Szidat, 1954; two Eucestoda, Valipora sp., and one undetermined metacestode; one nematode, Spinitectus asperus Travassos, Artigas \& Pereira, 1928; and one acanthocephalan, Neoechinorhynchus prochilodorum Nickol \& Thatcher, 1971. The sex of the host did not influence parasite indexes. The total length of the hosts influenced the abundance of S. nanii $\left(r_{s}=-0.21, p=0.01\right)$ and the prevalence of the metacestode $(r=-0.91, p=0.01)$. Saccocoelioides nanii was the dominant species in the parasite fauna of $P$. argenteus. Saccocoelioides nanii, Valipora sp., S. asperus and N. prochilodorum are reported here for the first time in $P$. argenteus and their known distribution is expanded to the São Francisco River.
\end{abstract} KEY WORDS. Helminths; Neoechinorhynchus; Saccocoelioides; Spinitectus; Valipora.

Prochilodus argenteus Spix \& Agassiz, 1829, popularly known as "curimatá-pacu" and Prochilodus costatus Valenciennes, 1850, known as "curimatá-pioa", are the only species of Prochilodus Agassiz, 1829 found in the São Francisco River and are both endemic to this basin. The curimatá-pacu, a detritivorous species (Alvim \& Peret 2004), is the largest of the family, reaching up to $15 \mathrm{~kg}$ and is of great economic importance in the region of the Três Marias Reservoir, State of Minas Gerais, Brazil, accounting for roughly $50 \%$ of the total fish catch (SATo et al. 1996). It is a long-distance migratory fish and reproduces between November and January (SATO et al. 2005).

There are reports of various species of helminths in Prochilodontidae. In $P$. argenteus metacercariae of Austrodiplostomum sp. were found by BrasiL-Sato (2003). The following helminths were reported in Prochilodus lineatus (Valenciennes, 1837): the digeneans Sanguinicola argentinensis Szidat, 1951, Saccocoelioides elongatus Szidat, 1954, Saccocoelioides nanii Szidat, 1954 and Saccocoelioides sp. according to Travassos et al. (1969), KoHn (1985) and Fernandes \& KoHn (1994); the nematodes Spinitectus asperus Travassos, Artigas \& Pereira, 1928 (senior synonym of $S$. jamundensis Thatcher \& Padilha, 1977) by Travassos et al. (1928), RAmallo et al. (2000), larval forms of the nematodes Procamallanus sp. according to KoHN et al. (1985) and Contracaecum sp. following Moravec et al. (1993); and the acanthocephalans Neoechinorhynchus variabilis (Diesing, 1851) (see
Travassos et al. 1928) and Neoechinorhynchus curemai Noronha, 1973 (see KoHn et al. 1985, Martins et al. 2000). LizAma et al. (2005) recorded the following endohelminths from $P$. lineatus: Megacoelium sp., Colocladorchis sp., Lecithobotrioides sp. (junior synonym of Saccocoelioides Szidat, 1954), Saccocoelioides magnorchis Thatcher, 1978, S. nanii, S. saccodontis Thatcher, 1976 (senior synonym of Saccocoelioides leporinodus Thatcher, 1978), Saccocoelioides sp., Unicoelium prochilodorum Thatcher \& Dossman, 1975, and two indeterminate digeneans, plerocercoids of Proteocephalidea and Valipora campylancristota (Wedl, 1855), the nematode Raphidascaris sp., and juvenile acanthocephalans of N. curemai and Quadrigyrus sp. In Prochilodus reticulatus Valenciennes, 1850 the digeneans Lecithobotrioides medicanoensis Thatcher \& Dossman, 1974 (junior synonym of S. elongatus) and $U$. prochilodorum, and the nematode $S$. jamundensis (junior synonym of $S$. asperus) were described. In Prochilodus nigricans Spix $\&$ Agassiz, 1829, an undetermined acanthocephalan species, Neoechinorhynchus sp. (see TANTALEón et al. 2005) was recorded.

This study introduces the helminths found in the digestive system of $P$. argenteus, one of the most important commercial fish in the upper São Francisco River (SATO et al. 2005), and evaluates the possible influence of the sex and total length of the fish on their parasite indexes. Additionally, the covariation between the helminth species and the dominant species of in the helminth community are presented. 


\section{MATERIAL AND METHODS}

A total of 150 specimens of $P$. argenteus were collected in July, 2003 and January, 2004 from the Upper São Francisco River, downstream from the Três Marias Dam (18 ${ }^{\circ} 12^{\prime} 32^{\prime \prime} \mathrm{S}, 45^{\circ} 15^{\prime}$ $41^{\prime \prime}$ W), State of Minas Gerais, by fishermen from the Estação de Hidrobiologia e Piscicultura da Companhia de Desenvolvimento dos Vales do São Francisco e do Parnaíba (EPT/CODEVASF). Fiftythree specimens were males varying from 24.8 to $40.2 \mathrm{~cm}$ total length $(28.73 \pm 4.37)$, and 97 specimens were females with total length varying from 23.3 to $40.8 \mathrm{~cm}(29.9 \pm 7.7)$.

The host was identified following BRITSKI et al. (1988) and the valid name of each host species follows CASTRO \& VARI (2003). Author's name, valid scientific names and in some cases the citations for the respective synonyms follow the www.fishbase.org (Froese \& Pauly 2009).

The organs of the digestive system and the coelom of each fish were separated and examined for parasites. The Endohelminths collected were fixed and processed following Amato et al. (1991) and Eiras et al. (2000).

Digeneans were identified according to Travassos et al. (1969) and classified following Jones (2005) and Overstreet \& Curran (2005), and eucestodes were identified to genus according to BonA (1994), following the classification cited by SPASSKY (1995). Metacestodes were found encysted in large numbers along the viscera, and it was not possible to count them. Nematodes were identified and classified according to Travassos et al. (1928) and MORAVEc (1998), respectively, and acanthocephalans were identified following Nickol \& THATcher (1971) and classified according to Amin (1987). Ecological terms, prevalence, mean intensity, mean abundance and site of infection follows BusH et al. (1997).

The ecological analyses included only helminths with prevalence higher than 10\%, in accordance with Bush et al. (1990). The Student's t-test (t) was used to compare total host length between males and females. Spearman's rank correlation coefficient $\left(\mathrm{r}_{\mathrm{s}}\right)$ was used to calculate possible correlations between total host length and parasitic intensity and abundance. Pearson's coefficient correlation (r) was used to indicate the relationship between total host length and prevalence of helminths, with arcsene transformation of data $(\operatorname{arcsen} \sqrt{\chi})$. The Chi-square test $\left(\chi^{2}\right)$ with Yate's correction and $2 \times 2$ contingency table was used to evaluate the prevalence of the parasites in relation to host sex. The Mann-Whitney test (U) was used to evaluate the parasitic intensity and abundance in relation to host sex. The possible covariation among the prevalence and abundance of parasite species was analyzed using Chi-square $\left(\chi^{2}\right)$ test and Spearman's rank correlation coefficient $\left(\mathrm{r}_{\mathrm{s}}\right)$, respectively.

The statistical analysis followed ZAR (1996) and the statistical significance was $p \leqslant 0.05$. The dominance frequency, the frequency of shared dominance and the relative dominance of each parasite species were calculated according to RoHDE et al. (1995). Voucher specimens of P. argenteus were deposited in the Museum of Zoologia of the Universidade de São Paulo (USP), State of São Paulo, Brazil (MZUSP 95167). Voucher specimens of helminths were deposited in the Coleção Helmintológica do Instituto Oswaldo Cruz (CHIOC), State of Rio de Janeiro, Brazil (see respective deposit numbers below).

\section{RESULTS}

A total of 3,464 specimens were found (3,235 adults and 229 larvae) belonging to five species of helminths: $S$. nanii (Digenea, Haploporoidea, Chalcinotrematinae), CHIOC 36917, 36918a, b; Valipora sp. (Eucestoda, Cyclophyllidea, Gryporhynchidae) CHIOC 36914a, b, c; an unidentified metacestode (Eucestoda) CHIOC 36913a, b, c (these specimens were not included in the total sum of larvae); S. asperus (Nematoda, Spirurida, Cystidicolidae), CHIOC 36915a, 35916a, b and Neoechinorhynchus prochilodorum Nickol \& Thatcher, 1971 (Acanthocephala, Eoacanthocephala, Neoechinorhynchidae), CHIOC 36919, 36920, and their ecological parameters are presented in table I. All these helminth species are reported here for the first time in $P$. argenteus, thus

Table I. Helminths and their parameters of infection of $P$. argenteus from the Upper São Francisco River, Minas Gerais. (SD) Standard deviation.

\begin{tabular}{lccccc}
\hline \multicolumn{1}{c}{ Helminths } & Prevalence (\%) & Range & Mean intensity \pm SD & Mean abundance \pm SD & Site of infection \\
\hline $\begin{array}{l}\text { Digenea } \\
\text { Saccocoelioides nanii }\end{array}$ & 64.0 & $1-177$ & $32.60 \pm 34.80$ & $20.80 \pm 31.90$ & Intestine \\
$\begin{array}{l}\text { Eucestoda } \\
\quad \text { Metacestode }\end{array}$ & 14.0 & ND & ND & ND & Intestine serous \\
$\quad \begin{array}{l}\text { Valipora sp. (larvae) } \\
\text { Nematoda }\end{array}$ & 2.00 & $1-4$ & $2.300 \pm 1.50$ & $0.05 \pm 0.40$ & Gall bladder \\
$\quad \begin{array}{l}\text { Spinitectus asperus } \\
\text { Acanthocephala }\end{array}$ & 33.3 & $1-10$ & $2.40 \pm 2.30$ & $0.80 \pm 1.80$ & Stomach \\
$\quad$ Neoechinorhynchus prochilodorum & 4.70 & $1-2$ & $1.30 \pm 0.50$ & $0.06 \pm 0.30$ & Intestine \\
\hline
\end{tabular}

(ND) Not determined. 
expanding their geographic distribution to the São Francisco River. Of the total of 150 fish examined, 98 (65.3\%) were parasitized, $63(42.0 \%)$ of them with only one species of parasite, $24(16.0 \%)$ with two, six $(4.0 \%)$ with three, and five $(3.3 \%)$ with four species. The total length of the female fish was significantly higher than that of the corresponding male $(t=2.02 ; \mathrm{p}=0.044)$.

Saccocoelioides nanii was the dominant species in the parasite community of $P$. argenteus, followed by $S$. asperus and the metacestodes (Tab. II). The parasitic parameters were not influenced by the sex of the host (Tab. III). Saccocoelioides nanii was significantly more abundant in smaller hosts $\left(r_{s}=-0.21\right.$, $\mathrm{p}=0.01)$. It was true for prevalence of the metacestodes found in the intestine $(\mathrm{r}=-0.91, \mathrm{p}=0.001)$ (Tab. IV). There was covariation in the prevalence $\left(\chi^{2}=11.103, p=0.0009\right)$ and abundance $\left(r_{s}=0.30, p<0.0001\right)$ between $S$. nanii and S. asperus.

\section{DISCUSSION}

According to the results of the present study, the helminth fauna of $P$. argenteus in the upper São Francisco River bears some similarity with that of $P$. lineatus from the Paraná River reported by Lizama et al. (2005). This resemblance is mostly due to shared species of Saccocoelioides Szidat, 1954, Neoechinorhynchus

Table II. Dominance analyses of helminths of $P$. argenteus from the Upper São Francisco River, Minas Gerais. (SD) Standard deviation.

\begin{tabular}{lccc}
\hline \multicolumn{1}{c}{ Helminths } & $\begin{array}{c}\text { Frequency of } \\
\text { dominance }\end{array}$ & $\begin{array}{c}\text { Shared } \\
\text { dominance }\end{array}$ & $\begin{array}{c}\text { Mean relative } \\
\text { dominance } \pm \text { SD }\end{array}$ \\
\hline Saccocoelioides nanii & 95 & 2 & $0.62 \pm 0.46$ \\
Spinitectus asperus & 11 & 2 & $0.10 \pm 0.26$ \\
\hline
\end{tabular}

Hamann, 1892 (adult specimens) and Valipora Linston, 1927 (larvae). Adult digeneans stood out quantitatively, with $S$. nanii being the dominant species in $P$. argenteus. The significant covariation of the $S$. nanii - S. asperus pair in P. argenteus from the São Francisco River found in this study and the observation of helminths in Prochilodus spp. (besides digeneans, cestode larvae, nematodes - especially Spinitectus spp., and acanthocephalans - Neoechinorhynchus spp.) in other watersheds (LizAma et al. 2005) indicate that the transmission of these parasites to their definitive hosts may be through close intermediate hosts or through hosts that are more abundant in their habitats.

The presence of larvae of Valipora sp. in P. argenteus from the São Francisco River and in P. lineatus from the Paraná River (LizAma et al. 2005) is consistent with the hypothesis that the Prochilodontidae act as intermediate hosts in the life cycle of bird helminths, especially Ciconiiformes and Ardeidae (BonA 1994), in Brazil. ScHolz et al. (2004) listed a wide spectrum of fish species used as hosts by these parasites, while stressing the absence of any definitive host records in various places where these metacestodes have been reported (e.g., South America). According to the authors, there are very few reports of larval pathogenesis in fish, but other studies will be necessary to clarify the subject.

Host total length as a reflection of age is an important factor in the variation of parasite infracommunities (DogIel 1961). In the present work, the abundance of $S$. nanii was higher in smaller (presumably younger) fish, a fact that may result from peculiarities of the fish immune system, or influenced by the feeding habits (smaller fish can use resources that are not accessible to adults) or the environments frequented by young fish, with higher concentration of metacercariaes in vegeta-

Table III. Analysis of the influence of the sex of $P$. argenteus from the Upper São Francisco River, Minas Gerais, on the parasitic prevalence $\left(\chi^{2}\right)$, intensity $(U)$ and abundance $(U) .\left(\chi^{2}\right)$ Chi-square with Yate's correction, $(U)$ Mann-Whitney test.

\begin{tabular}{|c|c|c|c|c|c|c|}
\hline \multirow{2}{*}{ Helminths } & \multicolumn{2}{|c|}{ Prevalence } & \multicolumn{2}{|c|}{ Intensity } & \multicolumn{2}{|c|}{ Abundance } \\
\hline & $\chi^{2}$ & $\mathrm{p}$ & U & $\mathrm{p}$ & $\mathrm{U}$ & $\mathrm{p}$ \\
\hline Saccocoelioides nanii & 0.02 & 0.88 & 983.00 & 0.58 & 2553.00 & 0.96 \\
\hline Metacestode & 0.28 & 0.59 & ND & ND & ND & ND \\
\hline Spinitectus asperus & 1.32 & 0.25 & 218.00 & 0.751 & 2326.50 & 0.251 \\
\hline
\end{tabular}

* Significant values, level of significance $p<0.05$; (ND) not determined.

Table IV. Analysis of the influence of total length of $P$. argenteus from the Upper São Francisco River, Minas Gerais, on the parasitic prevalence (r), intensity (rs) and abundance (rs). (r) Pearson correlation, (rs) Spearman's rank correlation coefficient.

\begin{tabular}{|c|c|c|c|c|c|c|}
\hline \multirow{2}{*}{ Helminths } & \multicolumn{2}{|c|}{ Prevalence } & \multicolumn{2}{|c|}{ Intensity } & \multicolumn{2}{|c|}{ Abundance } \\
\hline & $r$ & $\mathrm{p}$ & rs & $\mathrm{p}$ & rs & $\mathrm{p}$ \\
\hline Saccocoelioides nanii & -0.65 & 0.08 & -0.11 & 0.28 & -0.21 & $0.01^{*}$ \\
\hline Metacestode & -0.91 & $0.001^{*}$ & ND & ND & ND & ND \\
\hline Spinitectus asperus & -0.43 & 0.30 & 0.23 & 0.11 & -0.02 & 0.77 \\
\hline
\end{tabular}

* Significant values, level of significance $p<0.05$; (ND) not determined. 
tion. One or all of these factors together can be implicated in the higher abundance of $S$. nanii in smaller fishes. Lizama et al. (2005), however, did not find a correlation between the parasitic parameters and host length.

Another important biotic factor determining the parasite communities of some fish species is host sex (Dogrel 1961). Even though sex was not found to affect parasite indexes in $P$. argenteus, a positive influence was reported for $P$. lineatus (LizAmA et al. 2005). The lack of a correlation in our results may be explained by mininal behavioral and physiological differences between males and females of $P$. argenteus.

Among the helminths found, only $S$. asperus, which parasitizes the stomach of $P$. argenteus, is known to cause tissue lesions. RAmAllo et al. (2000) reported macro- and microscopic lesions caused by this nematode in the cardiac and pyloric stomach regions of $P$. lineatus. Macroscopic lesions caused by $S$. asperus were not observed in the present research. This study and some others on the parasitic fauna of endemic fishes from the Upper São Francisco River (Brasil-SATo 2002, Brasil-Sato \& SANTOS 2003, 2005, SANTos \& Brasil-Sato 2004, 2006) found that host sex did not influence parasite indexes. The relationship between standard lengths with parasitic indexes was reported to be variable, e.g.: a significant negative correlation between the prevalence of and a significant positive correlation between the intensity of Neoechinorhynchus pimelodi Brasil-Sato \& Pavanelli, 1998 and the standard length of Pimelodus maculatus Lacépède, 1803 from the São Francisco River (Brasil-Sato \& Pavanelli 1999); Santos \& BrasilSATo (2004) found that the prevalence of $N$. pimelodi also showed a negative correlation with the length of Franciscodoras marmoratus (Reinhardt, 1874). For the other parasites of $F$. marmoratus and for those of Salminus brasiliensis (Cuvier, 1817) and Conorhynchos conirostris (Valenciennes, 1840), no correlation was observed between the parasitic indexes and the total length of the hosts according to SANTOS \& BRASIL-SATO (2006), Brasil-Sato (2002) and Brasil-Sato \& Santos (2005), respectively.

The influence of sex and age on the metazoan parasites of $P$. lineatus was analyzed by LizAma et al. (2005). In this host, a positive correlation between host length and parasitic abundance was found only for $S$. nanii and $S$. magnorchis. In $P$. argenteus the abundance of $S$. nanii was negatively correlated with the total host length. In P. argenteus the sex of the hosts did not influence the parasitic indexes.

\section{ACKNOWLEDGEMENTS}

Thanks to Yoshimi Sato, leader of the Hydrobiology and Fish Culture Station of CODEVASF for the resources, to CEMIGGT/CODEVASF for the working arrangement, to UFRRJ/IBAMA (MG) technical-scientific agreement co-operation for providing logistical and material support; to the anonymous reviewers for the corrections and suggestions presented to the manuscript; to Philip J. Scholl for English revision, and to Capes and CNPq for a graduate scholarship grant to the first and second authors, respectively.

\section{LITERATURE CITED}

Alvim, M.C.C.; Peret, C.C. 2004. Food resources sustaining the fish fauna in a section of the Upper São cisco River in Três Marias, MG, Brazil. Brazilian Journal of Biology 64 (2): 195-202.

Amato, J.F.R.; W.A. Boeger \& S.B. Amato. 1991. Protocolos para laboratório - coleta e processamento de parasitos de pescado. Rio de Janeiro, Imprensa Universitária, Universidade Federal Rural do Rio de Janeiro, 81p.

Amin, O.M. 1987. Keys to the families and subfamilies of Acanthocephala with the erection of a new class (Polyacanthocephala) and a new order (Poliacanthorhynchida). Journal of Parasitology 73 (6): 1216-1219.

Bona, F.V. 1994. Family Dilepididae, p. 443-554. In: L.F. KhaliL; A. JoNES \& R.A. BRAY (Eds). Keys to the cestode parasites of vertebrates. Wallingford, $\mathrm{CAB}$ International, $655 \mathrm{p}$.

BRASIL-SATO, M.C. 2002. Digenea of Salminus brasiliensis (Cuvier, 1817) (Osteichthyes, Characidae) of the São Francisco River Basin, Brazil. Revista Brasileira de Parasitologia Veterinária 11 (2): 95-98.

Brasil-Sato, M.C. 2003. Parasitos de peixes da bacia do São Francisco, p. 149-165. In: H.P. GodinHo; A.L. Pereira (Eds). Águas, peixes e pescadores do São Francisco das Minas Gerais. Belo Horizonte, PUC Minas, 458p.

Brasil-Sato, M.C. \& G.C. Pavanelli. 1999. Ecological and reproductive aspects of Neoechinorhynchus pimelodi Brasil-Sato and Pavanelli (Eoacanthocephala, Neoechinorhynchidae) of Pimelodus maculatus Lacépède (Siluroidei, Pimelodidae) of the São Francisco River, Brazil. Revista Brasileira de Zoologia 16 (1) 73-82.

Brasil-Sato, M.C. \& M.D. Santos. 2003. Helmintos de Myleus micans (Lütken, 1875) (Characiformes: Serrasalminae) do Rio São Francisco, Brasil. Revista Brasileira de Parasitologia Veterinária 12 (2): 131-134.

Brasil-SATo, M.C. \& M.D. Santos. 2005. Metazoan parasites of Conorhynchos conirostris (Valenciennes, 1840), an endemic siluriform fish of the São Francisco Basin, Brazil. Revista Brasileira de Parasitologia Veterinária 14 (2): 160-166.

BRITSKI, H.A.; Y. SATO \& A.B.S. Rosa 1988. Manual de identificação de peixes da região de Três Marias (com chaves de identificação para os peixes da Bacia do São Francisco). Brasília, CODEVASF, Câmara dos Deputados, 115p.

Bush, A.O.; J.M. Ано \& C.R. Kennedy. 1990. Ecological versus phylogenetic determinants of helminth parasite community richness. Evolutionary Ecology 4 (1): 1-20.

Bush, A.O.; J.M. Lafferty \& A. Shostak. 1997. Parasitology meets ecology on its own terms: Margolis et al. revisited. Journal of Parasitology 83 (1): 575-583.

Castro, R.M.C. \& R.P. Vari. 2003. Family Prochilodontidae, p. 65-70 In: R.E. Reis; S.O. Kullander; C.J. Ferraris Jr (Eds). Check list of the freshwater fishes of South and Central America. Porto Alegre, EDIPUCRS, 742p. 
Dogiel, V.A. 1961. Ecology of parasites of freshwater fishes, p. 1-47. In: V.A. Dogiel; I.Y. Petrushevski (Eds). Parasitology of Fishes. London, Oliver and Boyd, 47p.

Eiras, J.C., R.M. Takemoto \& G.C. Pavanelli. 2000. Métodos de estudo e técnicas laboratoriais em parasitologia de peixes. Maringá, EDUEM, 121p.

Fernandes, B.M.м.;A. KoHn. 1994. On some trematodes parasites of fishes from Paraná River. Brazilian Journal of Biology 61 (3): 461-466.

Froese, R. \& D. Pauly. Editors. 2009. FishBase.Available online at: www.fishbase.org, version [Accessed: 10/XI/2009].

Jones, A. 2005. Superfamily Haploporoidea Nicoll, 1914, p. $127-$ 165. In: A. Jones; R.A.L. Bray; D.I. Kohn, A. 1985. On the species described by Szidat in 1954 in the genus Saccocoelioides (Digenea: Haploporidae). Memórias do Instituto Oswaldo Cruz 80 (4): 387-393.

Kohn, A.; B.M.M. Fernandes; B. Macedo \& B. Abramson. 1985. Helminths parasites of freshwater fishes from Pirassununga, SP, Brazil. Memórias do Instituto Oswaldo Cruz 80 (3): 327-336.

Lizama, M. De los A.P.; R.M. Takemoto \& G.C. Pavanelli. 2005. Influence of host sex and age on infracommunities of metazoan parasites of Prochilodus lineatus (Valenciennes, 1836) (Prochilodontidae) of the upper Paraná River floodplain, Brazil. Parasite 12 (4): 299-304.

Martins, M.L.; R.Y. Fujimoto; P.M. Andrade \& M. Tavares-Dias. 2000. Recent studies on Neoechinorhynchus curemai Noronha, 1973 (Acanthocephala: Neoechinorhynchidae), in Prochilodus lineatus Valenciennes, 1836, from Volta Grande Reservoir, MG, Brazil. Revista Brasileira de Biologia 60 (3): 517-522.

Moravec, F. 1998. Nematodes of freshwater fishes of the Neotropical Region. Praha, Academy of Sciences of the Czech Republic, 464p.

Moravec, F.; A. Kohn \& B.M.M. Fernandes. 1993. Nematode parasites of fishes of the Paraná River, Brazil. Part 2. Seuratoidea, Ascaridoidea, Habronematoidea and Acuarioidea. Folia Parasitologica 40 (1): 115-134.

Nickol, B.B. \& V.E. Thatcher. 1971. Two new acanthocephalans from Neotropical fishes: Neoechinorhynchus prochilodorum n.sp. and Gorytocephalus plecostomorum gen. et sp. nov. Journal of Parasitology 57 (3): 576-581.

Overstreet, R.M. \& S.S. Curran. 2005. Family Haploporidae Nicoll, 1914, p. 129-165. In: A. Jones; R.A.L. Bray \& D.I. GibsoN
(Eds) Keys to Trematoda. Wallingford, CABI Publishing and The Natural History Museum, vol. 2, 745p.

Ramallo, G.; H. Teran \& E. Teisaire. 2000. Effects produced by Spinitectus jamundensis (Nematoda, Cystidicolidae) in the stomach of the shad, Prochilodus lineatus (Pisces, Prochilodontidae). Boletin Chileno de Parasitologia 55 (1-2): 3638.

Rohde, K.; C. Hayward \& M. Heap. 1995. Aspects of the ecology of metazoan ectoparasites of marine fishes. International Journal for Parasitology 25 (8): 945-970.

Sato, Y.; E.L. Cardoso; A.L. Godinho \& H.P. Godinho. 1996. Hypophysation parameter of the fish Prochilodus marggravii obtained in routine hatchery station conditions. Brazilian Journal of Biology 56 (2): 59-64.

Sato, Y.; N. Bazzoli; E. Rizo; M.B. Boschi \& M.O.T. Miranda. 2005. Influence of the Abaeté River on the reproductive success of the Neotropical migratory teleost Prochilodus argenteus in the São Francisco River, downstream from the Três Marias dam, southeastern Brazil. River Research and Applications 21 (8): 939-950.

Santos, M.D. \& M.C. Brasil-Sato. 2004. Parasitos metazoários de Franciscodoras marmoratus (Reinhardt, 1874), "serrudo" (Siluriformes, Doradidae) do Rio São Francisco, Brasil. Revista Brasileira de Parasitologia Veterinária 13 (1): 18-22.

Santos, M.D. \& M.C. Brasil-Sato. 2006. Parasitic community of Franciscodoras marmoratus (Reinhardt, 1874) (Pisces: Siluriformes, Doradidae) from the upper São Francisco River, Brazil. Brazilian Journal of Biology 66 (3): 931-938.

Scholz, T.; R.A. Bray; R. Kuchta \& R. Repová. 2004. Larvae of gryporhynchid cestodes (Cyclophyllidea) from fish: a review. Folia Parasitologica 51 (2-3): 131-152.

SPASSKY, A.A. 1995. Changes in the type symmetry in higher cestodes ontogeny. Doklady Biologicheskii Nauk 343: 571573.

Tantaleón, M.; L. Sánches; L. Gómez \& A. Huiza. 2005. Acantocéfalos del Peru. Revista Peruana de Biologia 12 (1): 83-92.

Travassos, L.; P. Artigas \& C. Pereira. 1928. Fauna helminthologica dos peixes de água doce do Brasil. Arquivos do Instituto Biológico 1: 5-67.

Travassos, L.; J.F.T. Freitas \& A. Kohn. 1969. Trematódeos do Brasil. Memórias do Instituto Oswaldo Cruz 67: 1-886.

ZAR, J.H. 1996. Biostatistical Analysis. New Jersey, Prentice Hall, Inc., 662p.

Submitted: 16.XII.2008; Accepted: 08.XII.2009.

Editorial responsibility: Marcus Vinicius Domingues 